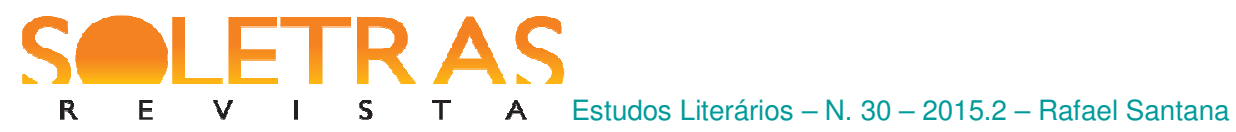

\title{
A Confissão de Lúcio e a crise da narrativa moderna
}

\author{
Rafael Santana ${ }^{1}$ \\ Universidade Federal do Rio de Janeiro
}

\begin{abstract}
Resumo: O romance, gênero textual do mundo burguês, nasce a partir da transição da sociedade aristocrática para a burguesa, entre fins do século XVIII e início do século XIX, assinalando uma crise na forma e no conteúdo da literatura, que passaria a ser expressa mormente em prosa e cuja temática estaria voltada, muitas vezes, para aqueles assuntos considerados corriqueiros, uma vez que o romance, ao ser composto para um público leitor ampliado, visaria também a cumprir uma função pedagógica de engajamento. Na contramão da narrativa oitocentista, o romance do princípio do século $\mathrm{XX}$, inscrito na ideia da crise da mimesis, romperia com os padrões da narrativa do século XIX, evidenciando um abalo na estrutura do próprio texto. Este trabalho propõe uma análise de A Confissão de Lúcio - do escritor modernista Mário de Sá-Carneiro -, um dos primeiros romances a esgarçar o cânone da narrativa oitocentista em Portugal, assinalando a consciência da crise da representação. Para tanto, baseia-se nas teorias do romance de Georg Lukács, Ian Watt e Anatol Rosenfeld.
\end{abstract}

Palavras-chave: Narrativa oitocentista. Narrativa novecentista. Mário de Sá-Carneiro.

A palavra não é idêntica à realidade que nomeia porque entre o homem $e$ as coisas $e$ - mais profundamente, entre o homem e seu ser-interpõe-se a consciência de si (PAZ, 2003, p. 35-36).

Tempo revolucionário e contraditório, o século XVIII gesta em seu próprio corpo os ideais que servirão de bandeira ético-político-cultural para o século vindouro. Os acontecimentos históricos do final de setecentos despertariam o olhar do indivíduo para uma nova ética, o que, no campo das artes, viria a exigir a proposta de uma nova estética. Assim, o mundo ocidental assiste, entre fins do século XVIII e início do século XIX, ao surgimento de novos gêneros artísticos, porque, em consonância com as mudanças radicais ocorridas na Europa setecentista, e em conformidade com uma nova visão de mundo que se propagava, a arte teria necessariamente de mudar. Sabemos que toda vez que há um câmbio radical na visão de mundo de uma sociedade, há, paralelamente, uma grande mudança naquilo que tange às formas e às manifestações artísticas. Por isso, assiste o final do século XVIII ao surgimento de uma forma literária completamente nova, chamada romance. Veículo de educação do

\footnotetext{
${ }^{1}$ Professor Adjunto de Literatura Portuguesa da Universidade Federal do Rio de Janeiro (UFRJ); Doutor em Literatura Portuguesa pela mesma universidade, onde defendeu a tese intitulada Lições do Esfinge Gorda, sobre a prosa e a correspondência literária de Mário de Sá-Carneiro. Atua principalmente nos seguintes temas: Decadentismo, Modernismo e ecos do fim de século na literatura contemporânea. Tem artigos publicados no Brasil e no exterior.
} 
indivíduo burguês, perdido e aviltado pelos descompassos histórico-sociais, o romance romântico, através de sua idealização contestadora, e o romance realista, através de sua denúncia reformista, pretendiam ser "um relato autêntico da experiência humana" (WATT, 2007, p. 31), para que o seu leitor, ao mergulhar nos mares da escrita, também pudesse aprender com a história desses heróis desiludidos, muitas vezes retratados no avesso do modelo social inscrito na História Oficial oitocentista. Ao identificar-se com a trajetória das personagens de romance, o leitor de oitocentos absorveria a ética da sociedade burguesa, porque, denunciando a dissonância entre o discurso e o comportamento social, entre a teoria e a práxis, a escrita romanesca almejava ensinar o seu narratário a perseguir aquilo que século vitoriano compreendia como valores autênticos - honra, honestidade, igualdade, retidão comportamental, ética do trabalho -, despertando-o para uma consciência mais justa e humanitária. Frente ao princípio utilitarista do mundo burguês, o romance - forma concebida por essa sociedade - obedeceria a um ideal estético pedagógico de engajamento (no sentido mesmo sartriano do termo), sendo, também ele, compreendido como um instrumento que concorreria para a reforma social e para o aprimoramento dos costumes. Contudo, como assinala Octavio Paz,

A revolução burguesa proclamou os direitos do homem, mas ao mesmo tempo os pisoteou em nome da propriedade privada e do livre comércio; declarou sacrossanta a liberdade, mas a submeteu às combinações do dinheiro; e afirmou a soberania dos povos, a igualdade dos homens, enquanto conquistava o planeta, reduzia à escravidão velhos impérios e estabelecia na Ásia, na África e na América os horrores do regime colonial (PAZ, 2003, p. 222).

Neste trabalho, pretendemos discorrer acerca daquilo que A Confissão de Lúcio, narrativa do escritor modernista português Mário de Sá-Carneiro, apresenta de distintivo em relação ao romance tradicional, principalmente no tocante à sua estrutura. Por outras palavras, ao nos determos na análise dos elementos dessa diegese de Sá-Carneiro - enredo, personagem, tempo, espaço e narrador -, desejamos cotejá-los aos do romance do século XIX, no intuito de chamar a atenção para as diferenças básicas entre ambos, destacando, dessa forma, aqueles traços marcantes que assinalariam a modernidade da prosa do início do século XX, fruto da crise da narrativa oitocentista.

Embora a Geração de Orpheu seja mais conhecida por aquilo que legou ao mundo em termos de poesia, esse grupo de escritores também produziu narrativas em prosa 


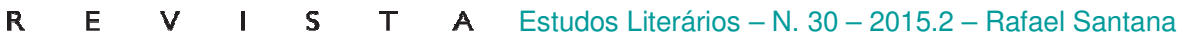

refinadíssima². É esse, por exemplo, o caso de A Confissão de Lúcio, de Mário de SáCarneiro, romance escrito numa prosa que aponta para as principais questões exploradas, de forma obsessiva, por muitos dos poemas compostos na mesma época, tais como a crise do sujeito, a desrealização do mundo, a inutilidade da ação, o escândalo e a rebeldia. Repare-se que esses seriam, justamente, alguns dos traços responsáveis por fazer com que essa diegese rompesse com muitos dos pressupostos máximos da literatura burguesa - instrumento de educação das massas -, vinculada por demais ao Romantismo e ao Realismo oitocentistas. Produzida em um momento de crise, de encruzilhada de estéticas, a pequena obra de Mário de Sá-Carneiro, tanto em poesia quanto em prosa, denuncia vínculos expressivos entre a literatura simbolista e a decadentista, assim como deixa patentes os primórdios da modernidade literária.

Claro está que esse período de crise provocaria, necessariamente, mudanças profundas no conjunto das artes, quer no que se refere ao projeto ideológico, quer no que tange ao processo de construção formal. Nesse sentido, ao lermos A Confissão de Lúcio, não se nos afigura dúvida de que o protagonista do romance é uma personagem inadaptada à sociedade que o circunda, ou seja, que ele é, como diria Georg Lukács (2007), um herói problemático. Entretanto, é paradoxalmente aí, no lugar em que se funda essa mesma certeza, que se encontra o reduto de nosso questionamento. Se, para Lukács, o herói problemático é aquele que está em busca de valores autênticos em um mundo degradado, reificado, marcado pela perda dos valores, e se esses valores se resumem, por exemplo, em honestidade, liberdade, igualdade, retidão etc., porque relacionados aos anseios da sociedade burguesa, como pensar, então, na questão do sentido da autenticidade para o indivíduo do século XX, claramente imbuído de uma ética antiburguesa? Com efeito, diante do esfacelamento dos antigos valores, o indivíduo novecentista viria a propor um outro parâmetro de valores autênticos, assinalando uma mudança que, certamente, seria refletida no campo da literatura. A esse respeito, escreve Anatol Rosenfeld:

Uma época com todos os valores em transição e por isso incoerentes, uma realidade que deixou de ser "um mundo explicado", exigem adaptações estéticas capazes de incorporar o estado de fluxo e insegurança dentro da própria estrutura da obra (ROSENFELD, 1996, p. 86).

Ora, o esfacelamento dos valores burgueses no campo ético provocaria igualmente um esfacelamento do constructo das artes, em outras palavras, no campo estético. Frente à ruína

\footnotetext{
${ }^{2}$ Como exemplos indiscutíveis de importantes narrativas produzidas por Orpheu estão, sem dúvida, Nome de Guerra, de Almada Negreiros, e o Livro do Desassossego, de Bernardo Soares, semi-heterônimo de Fernando Pessoa.
} 
do edifício ético vitoriano, a literatura do século XX direciona-se rumo a uma nova estética, capaz de refletir esse esgarçamento em sua própria estrutura, e de pôr em xeque o estatuto da realidade. E é precisamente com isso que nos encontramos, por exemplo, ao ler A Confissão de Lúcio.

Longe de vincular a sua obra a uma proposta pedagógica - tal como o fizeram muitos dos romancistas do século XIX -, ou seja, de fazer com que a obra de arte tivesse como finalidade a absorção de uma lição de moral por parte de seu leitor, porque relacionada a uma verdade, o narrador-autor de A confissão de Lúcio não manifesta certeza alguma acerca daquilo que relata, escolhendo, muitas vezes, o viés do inverossímil da verdade e da irrealidade da realidade ${ }^{3}$. A esse respeito, afirma José Carlos Barcellos:

Do ponto de vista da história da literatura, é importante ressaltar o contraste entre esse tipo de narrativa e os romances e contos do século XIX, sejam eles românticos, realistas ou naturalistas. Os narradores do século XIX, em geral, transmitem certezas e verdades a respeito das histórias que narram. Através dos conflitos vividos pelos personagens e das circunstâncias dos enredos, a palavra desses narradores é portadora de uma visão de mundo clara, coesa e coerente (que, evidentemente, varia muito de um autor para outro, mas é sempre a expressão de uma verdade bem definida).

Uma narrativa como A Confissão de Lúcio, ao contrário, nos deixa com dúvidas e questionamentos que o próprio narrador não sabe resolver. Essa mudança da postura do narrador aparece também no Simbolismo e no Decadentismo, e indica uma certa descrença nas formas tradicionais de conhecimento e representação da realidade, como a ciência, a filosofia e a própria literatura (BARCELLOS, 2007, p. 106-107).

Se a estética realista do século XIX tentara fazer crer num conceito de arte como espelho da realidade, arte como representação da verdade, as narrativas da modernidade inaugural do século $\mathrm{XX}$, ao contrário, se quiseram impor, propositadamente, como ficção, máscara, tessitura, jogo de linguagem. São essas, por exemplo, algumas das questões com as quais nos deparamos ao mergulhar no universo ficcional de A Confissão de Lúcio. Nessa diegese, não obstante o narrador, no prólogo do livro, queira convencer-nos de que o seu discurso estaria pautado na verdade, isto é, de que a sua Confissão nada mais seria do que um simples documento, o leitor cedo se dá conta de que essa afirmação não passa de mero exercício do paradoxo, tão ao gosto decadentista, e de que essa narrativa se apresenta, sobretudo, como ludus, teatralização, jogo cênico. De fato, se atentarmos para o tecido dos significantes, que é precisamente o espaço em que as ideias tomam forma, perceberemos que o narrador-autor se utiliza, a todo o momento, de expressões que, justamente, negam o

\footnotetext{
${ }^{3}$ Referimo-nos ao fato de o narrador-personagem de A Confissão de Lúcio dizer ao leitor que o seu relato seria sempre verdadeiro, por mais que essa verdade lhe parecesse inverossímil.
} 
estatuto da verdade, além de, constantemente, dar vazão ao seu inconsciente, ressaltando, desse modo, o fato de a estória narrada estar a meio caminho entre o sonho e a realidade:

Cheguei. Um criado estilizado conduziu-me a uma grande sala escura, pesada, ainda que jogos de luz a iluminassem. Ao entrar, com efeito, nessa sala resplandecente, eu tive a mesma sensação que sofremos se, vindos do sol, penetramos numa casa imersa em penumbra.

Fui pouco a pouco distinguindo os objectos... E, de súbito, sem saber como, num rodopio nevoento, encontrei-me sentado em um sofá, conversando com o poeta e a sua companheira...

Sim. Ainda hoje me é impossível dizer se, quando entrei no salão, já lá estava alguém, ou se foi só após instantes que os dois apareceram. Da mesma forma, nunca pude lembrar-me das primeiras palavras que troquei com Marta - era este o nome da esposa de Ricardo.

Enfim, eu entrara naquela sala tal como se, ao transpor o seu limiar, tivesse regressado a um mundo de sonhos ( $C L$, p. 77 , grifos do autor $)^{4}$.

Como se vê, o primeiro encontro de Lúcio com Marta, personagem que com ele formará parte do núcleo central do narrado, é marcado por um clima de irrealidade e mistério, clima presente não apenas no trecho citado, mas impregnado no tecido de toda a obra. Atente-se, no fragmento acima, para certas marcas discursivas que concorreriam para criar uma ambiência pouco realista a esse quadro narrativo. Nele, o personagem-narrador não realiza efetivamente nenhuma ação, dizendo apenas que, "num rodopio nevoento", encontrara-se "sentado em um sofá, conversando com o poeta e a sua companheira". E, de fato, tal acontecimento se lhe afigurava a Lúcio, tão estranho, tão misterioso, tão irreal, tão inefável, que, no fundo, mais lhe parecia uma espécie de regresso a "um mundo de sonhos". Além disso, repare-se ainda na constante tonalidade subjetiva do discurso do narrador-personagem no trecho supracitado, e, também, em outras partes do romance, como, por exemplo, no seguinte fragmento: "Todo o cenário mudara [...]. Inundava-o um perfume denso, [...] uma brisa cinzenta com laivos amarelos - não sei porquê, pareceu-me assim”. ( $C L$, p. 38, grifos do autor). Escrita a partir de expressões dubitativas e de um reiterado discurso modalizante, A Confissão de Lúcio, diferentemente da maioria das narrativas compostas até aquele momento histórico, constitui um tecido discursivo capaz de aliviar as pretensas certezas e a objetividade.

$\mathrm{Na}$ mesma esteira da fronteira pouco discernível entre o consciente e o inconsciente, repare-se agora como o narrador (Lúcio) - por meio de paradoxos e de ironias, ao querer traçar um perfil psicológico de seu amigo, o poeta Ricardo de Loureiro -, embora afirme que o seu relato seja tecido apenas a partir de fatos, acaba por eximir-se, de certa maneira, de um

\footnotetext{
${ }^{4}$ Utilizaremos a abreviatura $C L$ para citações do romance. 


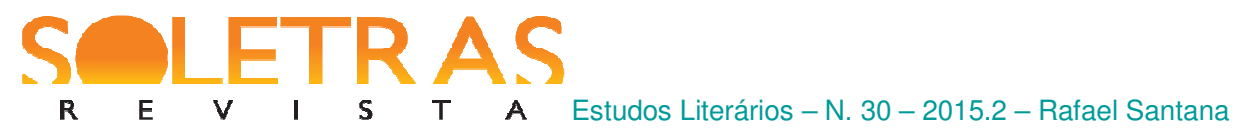

discurso assertivo, porque completamente nutrido de referências de caráter afetivo, e, por isso mesmo, muito difícil de serem mensuradas:

Largas horas, solitário, eu meditava nas singularidades do artista, a querer concluir alguma coisa. Mas o certo é que nunca soube descer uma psicologia, de maneira que chegava só a esta conclusão: ele era uma criatura superior - genial, perturbante. Hoje mesmo, volvidos longos anos, é essa a minha única certeza, e eis pelo que eu me limito a contar sem ordem - à medida que me vão recordando - os detalhes mais característicos da sua psicologia, como meros documentos na minha justificação.

Factos, apenas factos - avisei logo de princípio (CL, p. 57). (Grifos nossos).

Repare-se na incongruência entre esse retrato de uma "criatura superior", em que se afirmam a superioridade e a genialidade do poeta Ricardo de Loureiro, e o modo como o mesmo narrador nos alerta, em um outro momento da diegese, para que desconfiemos do modo como ele próprio tece a sua enunciação. Nesse segundo momento, desconfia Lúcio da "auréola de gênio" de Ricardo, e chega a sugerir que a "expressão nimbada" do poeta "não lhe pertencia”. Trata-se, sobretudo, de uma reflexão sobre a linguagem e a sua relação com o referente, que não pode ser recuperado de forma plena, seja na pintura, seja na literatura, seja nas artes em geral.

Os retratos que existem hoje do poeta, mostram-no belíssimo, numa auréola de génio. Simplesmente, não era essa a expressão do seu rosto. Sabendo tratar-se de um grande artista, os fotógrafos e os pintores ungiram-lhe a fronte de uma expressão nimbada que lhe não pertencia. Convém desconfiar sempre dos retratos dos grandes homens (CL, p. 68). (Grifos nossos).

Discurso constituído por fatos, relato objetivo de impressões subjetivas, verdade inverossímil, mas, ainda assim, não menos verdade, desse modo classifica a sua obra o narrador-autor de A Confissão de Lúcio. Texto urdido na linha do paradoxo, esse romance magistral de Sá-Carneiro aponta, ardilosamente, e a um só tempo, para a construção e para a desconstrução de um enunciado hipoteticamente pautado na vivência de uma realidade.

Narrativa claramente vinculada às inquietações do século $\mathrm{XX}$, A Confissão de Lúcio aponta para questões e prioridades muito distintas das exploradas pelo romance do século XIX. Por isso, para que seja possível viabilizar uma análise mais aprofundada e significativa dessa diegese de Sá-Carneiro, abordaremos, a seguir, algumas linhas mestras do romance oitocentista. Só então, no último subitem deste trabalho, voltaremos a enfatizar o modo inovador da narrativa do século XX, tomando sempre como parâmetro A Confissão de Lúcio, objeto-mor desta análise.

\section{O romance do século XIX: um gênero burguês}


Essa trapaça salutar, essa esquiva, esse logro magnífico que permite ouvir a língua fora do poder, no esplendor de uma revolução permanente da linguagem, eu a chamo, quanto a mim: literatura (BARTHES, 2007, p. 16).

Tempo de profundas mudanças no conjunto da sociedade - referimo-nos aos âmbitos político, econômico e cultural -, o século XIX instaura-se sob a égide da visão de mundo burguesa. Produto de um longo processo histórico - Revolução Comercial, Revolução Científica, Revolução Inglesa, Iluminismo, Independência dos Estados Unidos, Revolução Francesa, Revolução Industrial etc. - que concederia à burguesia, de forma definitiva, as rédeas do poder, esse século inova não só pelos câmbios que empreende nos espaços físicos e nas estruturas sociais das civilizações como um todo, mas, também, em termos psicológicos, por uma espécie de revolução na história das mentalidades. De fato, acontecimentos históricos como, por exemplo, o aprimoramento da indústria - que possibilitara a produção de mercadorias em larga escala - e a invenção da máquina a vapor e dos caminhos de ferro - que reduziram, de forma até então nunca vista, as coordenadas básicas de tempo e de distância seriam decisivos para uma alteração vertiginosa, tanto do sistema político-econômico das sociedades, quanto de sua ambiência ético-cultural. Tudo isso, como se sabe, acabaria por modificar, de forma significativa, o modo de viver e de pensar do mundo ocidental.

Dessa forma, compreendem-se facilmente as profundas diferenças que a cultura burguesa apresenta em relação a alguns conceitos como, dentre outros, os de família, matrimônio e trabalho, quando cotejada à do Antigo Regime. Por exemplo, da secular e extensa família aristocrática, que "abrange todas as pessoas que moram na mesma casa, inclusive criados, outros empregados, avós, primos e até parentes mais distantes" (WATT, 2007, p. 124), passa-se a uma família nuclear ou conjugal, restrita ao casal e seus filhos; do casamento contratual, pautado nas convenções de uma linhagem de sangue, à união por amor, "resultado da livre escolha dos indivíduos envolvidos" (WATT, 2007, p. 122); do trabalho enquanto empreendimento desonroso, pertencente à esfera do pré-humano, à voga utilitarista, em que a atividade produtiva seria a definidora do caráter humano. Encontramo-nos, portanto, diante de um período novo, de uma sociedade nova, de indivíduos, enfim, com uma visão de mundo completamente nova.

Diante de um tão distinto quadro social, claro está que o conjunto das artes - incluam-se aí as formas literárias - não permaneceria - nem poderia permanecer - o mesmo. Para substituir os dois nobres gêneros textuais consagrados desde a Antiguidade, e ratificados 
ainda pela Era Clássica - a epopeia e a tragédia -, nascem outros dois - mais apropriados a retratar as inquietações da sociedade vitoriana - batizados, então, como romance e drama. Tais gêneros apresentariam diferenças significativas em relação aos antigos: passa-se do verso, fôrma fechada em sua totalidade, à prosa, forma que busca a sua totalidade ${ }^{5}$; do personagem como encarnação da coletividade ao personagem individual (geralmente em crise com a sociedade); do enredo, enquanto empreendimento coletivo, gesta de um povo, à vida concreta e única do personagem; do tempo mítico ou multissecular ao tempo histórico, reduzido a dimensões compatíveis com uma vida humana; do espaço mítico ou maravilhoso ao espaço mundano, reconhecível como similar ao da existência cotidiana.

Além disso, tanto o romance quanto o drama, como gêneros burgueses que são, ou que, pelo menos, parecem haver sido assim concebidos, no momento de sua gênese, interessar-seiam, justamente, por aqueles temas em consonância com a visão de mundo daquela civilização. Para a nova sociedade, que se estabelece a partir do final do século XVIII / início do século XIX, é o ser humano como indivíduo, como ser histórico situado no tempo e no espaço, o grande objeto de seu interesse.

Num período em que cada vez mais se frisava a consciência da historicidade humana, para a cultura de oitocentos, o homem não mais poderia ser compreendido como uma entidade atemporal e abstrata, isto é, como uma figura genérica e universal representante de uma coletividade, mas, sim, como um ser concreto e único, que só pode ser compreendido historicamente, ou seja, em função das coordenadas básicas de tempo e de espaço. Para a cultura burguesa, é a vida cotidiana, é o indivíduo em busca de sua própria realização, a matéria capaz de despertar o seu interesse. A aristocracia, por exemplo, valorizara a prática de atividades relacionadas ao distintivo da classe: só a música, a caça, a esgrima ou, até mesmo, o próprio ato da conversa poderiam fornecer matérias dignas de serem temas de suas obras de arte $^{6}$; para a burguesia e, muitas vezes, para os escritores burgueses, é a vida de pessoas comuns, as atividades realizadas por essas pessoas comuns, e não aquelas levadas a cabo por

\footnotetext{
5 A esse respeito, diz Lukács: "Epopeia e romance, ambas objetivações da grande épica, não diferem pelas intenções configuradoras, mas pelos dados histórico-filosóficos com que se deparam para a configuração. $\mathrm{O}$ romance é a epopeia de uma era para a qual a totalidade extensiva da vida não é mais dada de modo evidente, para a qual a imanência do sentido à vida tornou-se problemática, mas que ainda assim tem por intenção a totalidade. Seria superficial e algo meramente artístico buscar as características únicas e decisivas da definição dos gêneros no verso e na prosa" (LUKÁCS, 2007, p. 122).

${ }^{6}$ Um bom exemplo disso talvez seja, no caso da literatura portuguesa, a grande produção circunstancial de sua literatura aristocrática, vinculada ao mecenato. Além disso, lembre-se que grande parte da poesia do Cancioneiro Geral (1516), de Garcia de Resende, retrata, principalmente, algumas atividades artísticas da vida da corte.
} 
figuras mitológicas e/ou da nobreza, o centro para o qual, permanentemente, se voltaria o seu interesse. A esse respeito, escreve Ian Watt:

Parece que o interesse do romancista pela vida cotidiana de pessoas comuns depende de duas importantes condições gerais: a sociedade deve valorizar muito cada indivíduo para considerá-lo digno da sua literatura séria; e deve haver entre as pessoas comuns suficiente variedade de convicções e ações para que seu relato minucioso interesse a outras pessoas comuns, aos leitores de romances. Provavelmente essas condições só vieram a prevalecer em época mais ou menos recente, pois resultam do surgimento de uma sociedade caracterizada por aquele vasto complexo de fatores independentes que se denomina individualismo (WATT, 2007, p. 55).

O teórico inglês aborda, na citação acima, duas questões muito importantes: a primeira, a de que o interesse do romancista estaria relacionado, justamente, com a existência cotidiana de pessoas comuns, devendo as convicções e ações de tais pessoas interessar, também, a outras pessoas comuns; a segunda, a de que este novo gênero - o romance - seria composto, especialmente, para uma massa de indivíduos, que constituiria o público leitor evidentemente ampliado em relação aos séculos anteriores. Estamos, claramente, frente a uma nova concepção de literatura e a um universo literário mais democrático, que, como se sabe, visava cada vez mais à ampliação paulatina desse público leitor. De fato, o papel de aprendizagem conferido ao público, no interior dos próprios textos literários, viria a constituir uma das preocupações fundamentais da literatura burguesa. Por isso mesmo, ao lermos algumas narrativas escritas pela pena dos escritores de oitocentos, sejam elas romances, contos, ou novelas, deparamo-nos, não raro, com diálogos entre o autor e o leitor. Mais que isso: no campo da estrutura do romance, por exemplo, diversos elementos da narrativa pareceriam estar relacionados de forma a conferir ao texto um maior sentido humano. Porque, como afirma Ian Watt,

[...] o romance constitui um relato completo e autêntico da experiência humana e, portanto, tem a obrigação de fornecer ao leitor detalhes da história como a individualidade dos agentes envolvidos, os particulares das épocas e locais de suas ações - detalhes que são apresentados através de um emprego da linguagem muito mais referencial do que é comum em outras formas literárias (WATT, 2007, p. 31).

Os gêneros narrativos burgueses privilegiam as histórias de pessoas comuns, as suas idiossincrasias, a sua identificação com os temas prosaicos e a sua experiência cotidiana, sendo, ainda, compostos para uma massa ampliada de leitores, e servindo, muitas vezes, para a sua educação. Como se sabe, tanto a literatura romântica quanto a realista foram os grandes instrumentos pedagógicos de que dispunham os intelectuais do século XIX. Contudo, essa valorização do prosaico - entendido aqui como a retratação da vida comum no seu aspecto 
utilitário - levaria a sociedade burguesa a uma crescente desvalorização da poesia. Num mundo burguês, marcado por um discurso utilitarista, o verso, forma literária de prestígio desde a Antiguidade Clássica, perderia o seu posto de nobreza, cedendo espaço para a ascensão dos gêneros em prosa - romance, conto, novela -, considerados mais adequados para atender às exigências da literatura vitoriana. Propagando a ideia de que a obra de arte teria uma função social a cumprir, sendo inscrita sob o influxo de uma forte consciência pedagógica, e sendo ainda composta com vistas à educação de uma sociedade nova, a literatura burguesa pareceria não ter mesmo um espaço destinado à poesia. Encontrando uma grande dificuldade de adequar o princípio utilitarista de seu século à esfera do poema, o artista burguês, imerso numa ambiência social marcada pelo prosaísmo - descumpridora de suas promessas -, refletiria também sobre o tema da crise da poesia em uma sociedade fortemente marcada pela ética do trabalho, o que lhe despertaria o desejo de reivindicar, para o seu mundo sensabor, a magia inerente à atividade poética.

Almeida Garrett, no prefácio à Lírica de João Mínimo (1829) - coletânea de poemas de sua juventude -, afirma que a poesia perdera o seu espaço na sociedade do século XIX, diante daquilo que o autor chama de "a barafunda das malditas políticas" (2010, p. 5). E acrescenta, ainda, o escritor: [...] "Hoje a moda é prosa e mais prosa, economias políticas, estatísticas, químicas, físicas, e outras inúteis frandulagens [...]” (Ibidem). Na advertência às Folhas Caídas (1953) - obra poética de sua maturidade literária -, reitera Garrett acerca da poesia:

Os cantos que formam esta pequena colecção pertencem todos a uma época de vida íntima e recolhida que nada tem com as minhas outras colecções. Essas mais ou menos mostram o poeta que canta diante do público. Das Folhas Caídas ninguém tal dirá, ou bem pouco entende de estilos e modos de cantar.

Não sei se são bons ou maus estes versos; sei que gosto mais deles do que de nenhuns outros que fizesse. Porquê? É impossível dizê-lo, mas é verdade. E, como nada são por ele nem para ele, é provável que o público sinta bem diversamente do autor. Que importa? (GARRETT, 2009, p. 2-3).

"Poeta em anos de prosa" (GARRETT, 2005, p. 59, grifos do autor), como se autodenominou nas suas famosas Viagens na Minha Terra (1843), Garrett se pergunta onde residiria o espaço da poesia na vida social do século XIX: "Pois este é um século para poetas? Ou temos nós poetas para este século?..." (GARRETT, 2005, p. 59), questiona-se Almeida Garrett em sua obra-prima. E a conclusão a que parece chegar o escritor, na advertência às Folhas Caídas, é a de que os versos que canta nada têm a ver com aquilo que cantara diante do público e para o público, dado o caráter eminentemente intimista de toda literatura inscrita em poesia, bem de acordo com o modo como aquele momento histórico compreendia a 
atividade poética. Por isso, frente ao estranhamento que os seus versos causariam em seu público leitor - e que Garrett o sabia claramente -, pergunta-se o autor “Que importa?”, pois só para si mesmo os compunha. Desvinculada de questões políticas, e não necessariamente atrelada a um propósito social, a poesia perderia o seu status de nobreza na sociedade do século XIX, período em que o individualismo da cultura burguesa teria de ser, não raro, o portador de uma mensagem social, função cumprida geralmente, no espaço da literatura, pelo herói romanesco. Postas essas questões, estabeleçamos mais especificamente as diferenças marcantes entre as narrativas dos séculos XIX e XX, no item que se vai ler agora.

\title{
$O$ romance do século $\mathrm{XX}$ : uma ética antiburguesa
}

\author{
Eu vejo o futuro repetir o passado \\ Eu vejo um museu de grandes novidades \\ O tempo não para \\ Não para, não, não para. (CAZUZA)
}

No subitem anterior, vimos que o romance do século XIX, "epopeia da burguesia", forma textual dos novos tempos, apresenta diferenças marcantes em relação aos gêneros narrativos privilegiados pela Antiguidade e pela Era Clássica: a epopeia e a tragédia. Dentre essas diferenças, destacamos o forte caráter pedagógico do romance oitocentista, enfatizamos o modo pelo qual o indivíduo seria compreendido no século XIX, e apontamos para a maneira como esse mesmo indivíduo seria retratado pela narrativa daquela época. Ou seja, conforme vimos nos tópicos antecedentes, o homem seria, segundo a visão de mundo corrente naquele tempo, um ser, não atemporal e abstrato, mas concreto e único, e, nesse sentido, só poderia ser entendido historicamente, isto é, se situado num tempo e num espaço específicos, de acordo com os parâmetros da cultura burguesa, hegemônica naquele momento. Claro está que se, por um lado, ética e estética são dois fenômenos que caminham sempre juntos, como assinala uma série de estudiosos, e que se, por outro lado, o romance é um gênero literário em que a ética do romancista se converte em problema estético da obra, como bem afirma Georg Lukács (2007), natural seria, portanto, que a narrativa do século XIX manifestasse predileção pelos enredos tradicionais, pelo tempo cronológico, pelas personagens comuns, pelo espaço cotidiano, pela narração onisciente, pela vivência de uma verdade, enfim.

Ora, a estrutura do romance, ou seja, os mesmos elementos da narrativa de que tratamos ao falar do romance burguês - enredo, tempo, personagem, espaço e narrador - acabaria por sofrer mudanças significativas na viragem do século XIX para o século XX, momento a partir 
do qual uma nova ética viria a exigir a proposta de uma nova estética. A respeito do romance novecentista, por exemplo, dirá Anatol Rosenfeld:

Nota-se no romance do nosso século uma modificação análoga à da pintura moderna, modificação que parece ser essencial à estrutura do modernismo. À eliminação do espaço, ou da ilusão do espaço, parece corresponder a da sucessão temporal. A cronologia, a continuidade temporal foram abaladas, "os relógios foram destruídos". O romance moderno nasceu no momento em que Proust, Joyce, Gide, Faulkner começam a desfazer a ordem cronológica, fundindo passado, presente e futuro.

[...]

Com isso, espaço e tempo, formas relativas da nossa consciência, mas sempre manipuladas como se fossem absolutas, são por assim dizer denunciadas como relativas e subjetivas. A consciência como que põe em dúvida o seu direito de impor às coisas - e à própria vida psíquica - uma ordem que já não parece corresponder à realidade verdadeira. A dificuldade que boa parte do público encontra em adaptar-se a este tipo de pintura ou romance decorre da circunstância de a arte moderna negar o compromisso com este mundo empírico das "aparências", isto é, com o mundo temporal e espacial posto como real e absoluto pelo realismo tradicional e pelo senso comum. Trata-se, antes de tudo, de um processo de desmascaramento do mundo epidérmico do senso comum. Revelando espaço e tempo - e com isso o mundo empírico dos sentidos - como relativos ou mesmo como aparentes, a arte moderna nada fez senão reconhecer o que é corriqueiro na ciência e filosofia. Duvidando da posição absoluta da "consciência central" ela repete o que faz a sociologia do conhecimento, com sua reflexão crítica sobre as posições ocupadas pelo sujeito cognoscente (ROSENFELD, 1996, p. 80-81).

Apoiando-se na hipótese de que haja um certo Zeitgeist em cada fase histórica, Anatol Rosenfeld, em um texto intitulado Reflexões sobre o romance moderno, do qual a citação acima é parte integrante, propõe uma analogia entre a pintura e esse gênero literário. Segundo o autor, observa-se na pintura moderna um marcante fenômeno de desrealização, fenômeno que se manifestaria, principalmente, no fato de essa pintura ter deixado de ser mimética, isto é, de ela se recusar a reproduzir a realidade empírica tal qual o seria em sua aparência primeira. Como exemplo disso, o teórico em questão aponta para os traços mais marcantes das Vanguardas Europeias, as quais, segundo ele, apresentariam como denominador comum a negação da realidade sensível, ao rejeitar, de todos os modos possíveis, a instância da realidade, ou, em outras palavras, o próprio estatuto da verdade.

Segundo Ian Watt, por exemplo, o realismo seria precisamente aquele traço capaz de distinguir, da forma mais clara possível, os romances dos séculos XVIII / XIX da ficção anterior a esse tempo ${ }^{7}$. Como vimos, a narrativa oitocentista pretendia ser um relato autêntico

${ }^{7}$ É importante ressaltar que Ian Watt faz alusão ao termo "realismo", não para designar a estética assim nomeada, mas sim para referir-se às miudezas da vida cotidiana retratadas nos romances dos séculos XVIII / $\mathrm{XIX}$, assim como para referir-se ao enredo dessas narrativas, quase sempre compatível com o universo da 
da experiência humana, e, nesse sentido, queria transmitir ao seu leitor, sempre que possível, a máxima ilusão da realidade. No esforço de dar conta desse objetivo, os autores do século XIX, muitas vezes, apelaram em suas diegeses para a retratação de datas, locais e documentos, ainda que todos esses pormenores tivessem sido concebidos pela imaginação desses mesmos escritores. Na contramão da estrutura narrativa de oitocentos estaria o próprio romance de inícios do século $\mathrm{XX}$, romance que se preocuparia não mais com a tal prerrogativa da verdade, mas sim com dar vazão ao sonho e ao inconsciente, além de, a todo o momento, admitir-se como ficção, isto é, como trabalho de linguagem. A esse respeito, assinala Anatol Rosenfeld:

No romance do século passado a perspectiva, a plasticidade das personagens e a ilusão da realidade foram criadas por uma espécie de truque: o romancista, onisciente, adotando por assim dizer uma visão estereoscópica ou tridimensional, enfocava as suas personagens logo de dentro, logo de fora, conhecia-lhes o futuro e o passado empíricos, biográficos, situava-as num ambiente de cujo plano de fundo se destacavam com nitidez, realçavalhes a verossimilhança (aparência da verdade) conduzindo-as ao longo de um enredo cronológico (retrocessos no tempo eram marcados como tais), de encadeamento causal. O narrador, mesmo quando não se manifestava de um modo acentuado, desaparecendo por trás da obra como se esta se narrasse sozinha, impunha-lhe uma ordem que se assemelhava à projeção a partir de uma consciência situada fora ou acima do contexto narrativo. Por mais fictício que seja o imperfeito da narração, esta voz gramatical revela distância e indica que o narrador não faz parte dos sucessos, ainda que se apresente como Eu que alega narrar as próprias aventuras: o Eu passado já se tornou objeto para o Eu narrador. É digno de nota a grande quantidade de romances modernos narrados na voz do presente, quer para eliminar a impressão de distância entre o narrador e o mundo narrado, quer para apresentar a "geometria" de um mundo eterno, sem tempo.

O primeiro grande romancista que rompe a tradição do século XIX, conquanto ainda de modo moderado, é Marcel Proust: para o narrador do seu grau de romance o mundo já não é um dado objetivo e sim vivência subjetiva; o romance se passa no íntimo do narrador, as perspectivas se borram, as pessoas se fragmentam, visto que a cronologia se confunde no tempo vivido; a reminiscência transforma o passado em atualidade. Como o narrador já não se encontra fora da situação narrada e sim profundamente envolvido nela não há a distância que produz a visão perspectivística.

Quanto mais o narrador se envolve na situação, através da visão microscópica e da voz do presente, tanto mais os contornos nítidos se confundem; o mundo narrado se torna opaco e caótico (ROSENFELD, 1996, p. 91-92).

Ora, diversas das questões apontadas por Anatol Rosenfeld na citação acima podem ser encontradas em A Confissão de Lúcio. Em primeiro lugar, chamamos a atenção para o fato de esse romance ser narrado na voz do presente. Ou seja, após o cumprimento de dez anos de

experiência humana. Para o teórico inglês, seriam justamente esses os traços que fariam do romance um gênero literário muitíssimo mais realista do que a ficção anterior à sua existência. 
prisão, Lúcio, o narrador-personagem da estória, decide relatar os fatos que o levaram a viver tal situação. Em segundo lugar, queremos destacar o quanto esse narrador tem o poder de transformar o seu passado em atualidade, ao fazer de "um instante que focara toda a sua vida" $(C L$, p.18) não apenas o leitmotiv de sua escrita, como também o de sua própria existência. Em terceiro e último lugar, ressaltamos o quanto essa narração estaria comprometida pelo ponto de vista de um narrador em primeira pessoa, narrador que, a todo o momento, faz questão de conferir destaque ao caráter subjetivo de seu enunciado. Diegese composta sob a égide da modernidade, A Confissão de Lúcio derruba, também, as barreiras entre presente e passado, num discurso artístico em que a cronologia se confunde, de forma constante, com a do tempo vivido. E é justamente sobre esse fato que nos alerta o próprio narrador-personagem do romance, ao redigir o insólito prólogo de sua Confissão:

Ah! Foi bem curta - sobretudo para mim... Esses dez anos esvoaram-se-me
como dez meses. É que, em realidade, as horas não podem mais ter acção
sobre aqueles que viveram um instante que focou toda a sua vida. Atingido o
sofrimento máximo, nada já nos faz sofrer. Vibradas as sensações máximas,
nada já nos fará oscilar. Simplesmente, este momento culminante raras são
as criaturas que o vivem. As que o viveram ou são, como eu, os mortos-
vivos, ou - apenas - os desencantados que muita vez, acabam no suicídio
$(C L$, p. 18-19).

Ou ainda, quando esse mesmo narrador, no fim de sua obra, rompe completamente com a barreira do tempo, igualando o presente, o passado e o futuro:

Acho-me tranquilo - sem desejos, sem esperanças. Não me preocupa o futuro. O meu passado, ao revê-lo surge-me como o passado de um outro. Permaneci, mas já não me sou. E até à morte real, só me resta contemplar as horas a esgueirar-se em minha face... A morte real - apenas um sono mais denso...

Antes, não quis, porém deixar de escrever sinceramente, com a maior simplicidade, a minha estranha aventura. Ela prova como factos que se nos afiguram bem claros são muitas vezes os mais emaranhados; ela prova como um inocente, muita vez, se não pode justificar, porque a sua justificação é inverossímil - embora verdadeira ( $C L$, p. 164).

Além de denunciar os limites do tempo como imprecisos, numa espécie de entrecruzar de fios entre presente, passado e futuro, o narrador-autor de A Confissão de Lúcio utiliza-se, reiteradamente, de um recurso muitíssimo importante e significativo, recurso que se apresenta como um traço marcante de uma série de outras narrativas da modernidade inaugural do século XX: a écriture artiste. Para Latuf Isaias Mucci, tal recurso seria mais do que simplesmente "uma sofisticação na maneira de escrever, de transgredir o código da gramática, de estruturar, avidamente, figuras de retórica, de operar torneios frásticos" (Consulta em: 14/06/2012). Segundo ele, essa técnica implicaria "uma sensorialidade e, até, uma 


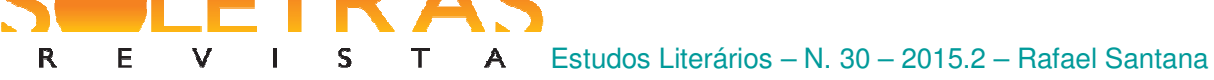

sensualidade no gesto escritural" (Consulta em: 14/06/2012). Portanto, mais do que um mero adorno da linguagem, a écriture artiste se apresentaria, sobretudo, como um postulado, como uma filosofia, sendo, por isso mesmo, para além de uma écriture artiste, uma écriture-dandy. Ou seja, um texto assentado no primado do simulacro e do artifício do signo.

Acabando de vez com a submissão tradicional do significante ao significado, o Decadentismo - estética da qual a escritura de Sá-Carneiro é herdeira -, para além de antecipar o conhecido divórcio que os escritores da modernidade inaugural do século $\mathrm{XX}$ empreenderam entre a literatura e a realidade, ao privilegiarem, não raramente, os labirintos do inconsciente, os caminhos fragmentários da memória e o assentamento da arte no tapete onírico das incertezas, procurou, também, dar ênfase àqueles traços escriturais que, em nossos tempos, nos permitem diferenciar, com clareza, os romances oitocentistas dos novecentistas. Sublinhando, sempre que possível, aqueles aspectos que, de forma consciente, fazem exibir, nas malhas do tecido discursivo, os traços mais representativos da literatura do início do século XX, período de incoerências, tempo que, no dizer de Anatol Rosenfeld, exigira "adaptações estéticas capazes de incorporar o estado de fluxo e insegurança dentro da própria estrutura da obra" (1996, p.86), Mário de Sá-Carneiro, por exemplo, na narrativa A Confissão de Lúcio, esgarça o paradigma diegético oitocentista, através de sua consciência aguda da escritura, através da inversão da mimesis, através da desconstrução do positivismo reinante. Nesse sentido, se a palavra dos narradores do século XIX, como diz José Carlos Barcellos, costumava ser, muitas vezes, "portadora de uma visão de mundo clara, coesa e coerente", ou melhor, de "uma verdade bem definida" (2007, p. 107), a palavra do narrador de A Confissão de Lúcio, ao contrário, tende a representar o mundo e as experiências pessoais, não mais como "um dado objetivo", mas sim como uma "vivência subjetiva" (ROSENFELD, 1996, p. 92). Seguindo ainda a linha da diferenciação entre as narrativas oitocentistas e novecentistas, vimos que um dos fatores de grande relevância no que concerne aos aspectos estruturais responsáveis pela distinção entre o romance do século XIX e o romance do século XX é a questão do tempo. Nas palavras de Anatol Rosenfeld, se o tempo é um traço muito bem delimitado nas narrativas de oitocentos, e se as digressões e os cortes temporais sofridos por essas narrativas são necessariamente marcados como tais, esse fator (o tempo) começaria a ser concebido como relativo na literatura do século XX, que buscou, propositadamente, "desfazer a ordem cronológica, fundindo presente, passado e futuro" (1996, p. 80). Essas duas questões tão caras à narrativa do Modernismo constituem, como se sabe, um dos eixos basilares do texto decadentista, com o qual Mário de Sá-Carneiro dialoga permanentemente em sua obra. 
Claro está que essa narrativa na qual a preocupação-mor reside prioritariamente na teatralização da escritura, no jogo dos significantes, apresenta vínculos expressivos com a poesia, ainda que esse tecido discursivo seja composto em prosa. Como genuinamente diz Octavio Paz em um texto magnífico, intitulado A Ambiguidade do Romance (2003), a crise da sociedade moderna, isto é, a ruína de todos os valores éticos de nosso mundo, manifesta-se esteticamente, na prosa do século XX, como uma espécie de regresso ao poema.

A crise da sociedade moderna - que é crise dos princípios de nosso mundo se manifestou no romance como um regresso ao poema. $\mathrm{O}$ movimento iniciado por Cervantes se repete agora, ainda que em sentido inverso, em Joyce, Proust e Kafka. Cervantes deriva o romance do poema épico burlesco; seu mundo é indeciso, como o da alvorada e daí o caráter alucinante da realidade que nos oferece. Sua prosa se limita às vezes com o verso, não só porque com certa frequência incorre em hendecassílabos e octossílabos, mas também pelo emprego deliberado de uma linguagem poética. Sua obsessão pela poesia se revela sobretudo na limpidez da linguagem de Los trabajos de Persiles y Segismunda, que ele considerava como a mais perfeita de suas obras e na qual abundam trechos que são verdadeiros poemas. À medida que são maiores as conquistas do espírito de análise, o romance abandona a linguagem da poesia e se aproxima à da prosa. Mas a crítica está destinada a refutar-se a si mesma. A prosa se nega como prosa. O autor de Madame Bovary é também o de Salambó e da Leyenda de San Julián el Hospitalario. Os triunfos da razão são também suas derrotas, segundo se vê em Tolstoi, Dostoievski, Swift ou Henry James. Desde os princípios do século o romance tende a ser poema de novo. Não é necessário sublinhar o caráter poemático da obra de Proust, com seu ritmo lento e suas imagens provocadas por uma memória cujo funcionamento não deixa de ter analogias com a inspiração poética.

E não só os escritos em prosa de Proust nos permitem observar o caráter poemático das obras modernas. É possível atentar para esse fato na própria produção romanesca sácarneiriana, em que a escritura, em nada comprometida com a verossimilhança, se quer impor como prosa poética, como exercício de linguagem, como produto do artifício. Ou seja, como narrativas tão debruçadas sobre um trabalho técnico em si mesmas, que a enunciação, por vezes, pareceria desejar ser superior ao próprio enunciado. Tecido urdido por um discurso lacunar, e comprometido, até ao extremo, pela fragilidade da memória, sempre incapaz de uma recuperação plena do passado, A Confissão de Lúcio parece negar, a todo o momento, o estatuto da realidade, apontando para traços muito distintos dos apresentados pelo romance dos séculos anteriores, traços que se adequariam, com perfeição, à narrativa de um mundo pautado, quase que exclusivamente, em dores e em incertezas.

\section{Referências bibliográficas:}




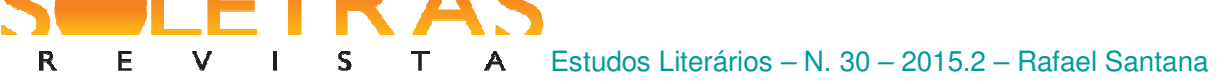

BARCELLOS, José Carlos. Literatura Portuguesa: Ficção. Rio de Janeiro: CCAA, 2007.

BARTHES, Roland. Aula. Trad. Leila Perrone Moisés. São Paulo: Cultrix, 2007.

GARRETT, Almeida. Lírica de João Mínimo. Porto: Ed. Porto, 2010.

- Viagens na minha Terra. São Paulo: Martin Claret, 2005.

LUKÁCS, Georg. A Teoria do Romance. Trad. José Marcos Mariani de Macedo. São Paulo: Livraria Duas Cidades; Editora 34, 2007.

MUCCI, Latuf Isaias. Écriture Artiste. Disponível em: http://www2.fcsh.unl.pt/edtl/ verbetes/E/ecriture_artiste.htm. Acesso em: 14 jun. 2012.

PAZ, Octavio. El Arco y la Lira. México: Fondo de Cultura Económica, 2003.

ROSENFELD, Anatol. Reflexões sobre o Romance Moderno. In: ROSENFELD, Anatol (Org.). Texto/Contexto I. São Paulo: Perspectiva, 1996, p. 75-98.

WATT, Ian. A Ascensão do Romance. Tradução de Hildegard Feist. São Paulo: Companhia das Letras, 2007.

\title{
A Confissão de Lúcio and the crisis of modern narrative
}

\begin{abstract}
The novel, textual genre of the bourgeois world, emerged with the transition from the aristocratic to the bourgeois society, between the end of the eighteenth and the beginning of the nineteenth century, pointing out a crisis in both form and content of literature, which would be mostly expressed in prose and whose subjects would be mainly focused on those themes that could be thought of as side issues, since the novel isconceived for a greater number of readers, would also aim to fulfill a pedagogical function for a socially engaged art. Against the nineteenth-century prose, the novel of the early twentieth century, taking part in the current debate on the crisis of mimesis, would break with the standards of the traditional romance, showing a perturbation in the structure of the text itself. The aim of this paper is to suggest a reading of A Confissão de Lúcio, by Mário de Sá-Carneiro, one of the first novels to break with the canon of the nineteenth-century narrative in Portugal, revealing the awareness of the crisis of representation. We base our study on the theories of romance proposed by Georg Lukács, Ian Watt and Anatol Rosenfeld.
\end{abstract}

Keywords: Nineteenth-century novel. Twentieth-century novel. Mário de Sá-Carneiro.

Recebido em: 11 de maio de 2015.

Aprovado em: 28 de dezembro de 2015 . 